\title{
BALIĆEV PRISTUP
}

\author{
Dario Škarica
}

Institut za filozofiju, Zagreb

Sveučilište u Splitu, Filozofski fakultet

Odsjek za filozofiju

dskarica@ffst.hr
UDK: 27-789.32Balić, K.

378.4(493.154.4)LOU:1Balić, K. 1Balić,K: 141.319

https://doi.org/10.34075/cs.55.1.5

Pregledni znanstveni rad Rad zaprimljen 9/2019.

\section{Sažetak}

Glauni je cilj ovog članka ponuditi cjelovit prikaz Balićeva neoskolastičkog pristupa. Istraživanjem raznih iskaza, uglavnom međusobno izoliranih $i$ rasutih po Balicevim radovima prema sredini $X X$. st., identificirane su sljedeće tri temeljne značajke Balićeva pristupa: prvo, historijsko-kritička metoda (izrijekom preferirana u odnosu na spekulativni pristup), drugo, privrženost rimokatoličkim dogmama kao jednoj od normi prema kojima vrednujemo filozofske sisteme $i$, treće, postojano zagovaranje načela intelektualne slobode i otvorenosti prema raznim skolastičkim sistemima kao i prema modernoj znanosti $i$ filozofiji (u okviru dogme).

Ključne riječi: Karlo Balić, povijesno-kritički pristup, integralna skolastika, louvainska neoskolastika.

\section{UvOD}

Godine 1923. uprava Franjevačke provincije Presvetog Otkupitelja šalje fra Karla Balića na postdiplomski studij teologije na Katoličkom sveučilištu u Louvainu. ${ }^{1}$ Sredinom XIX. st. to je Sveučilište bilo istaknuto središte ontologizma (protkana tradicionalističkim i

1 Usp. Gabrijel Hrvatin Jurišić, Sedamdeseta godišnjica života i rada fra Karla Balića (1899-1969), Kačić 3 (1970), 7-18 (na str. 8); Vicko Kapitanović, Fra Karlo Balić, medievalist i mariolog (6. XII. 1899-15. IV. 1977.), Služba Božja, 37 (1997), 3-4, 255-268 (na str. 256); Vicko Kapitanović, Dr. fra Karlo Balić. Pregled života i rada, u: Marko Babić (ur.), Aktualnost predaje. Zbornik radova Međunarodnoga znanstvenog skupa prigodom 100. obljetnice rođenja fra Karla Balića, Split, 06. XI.1999., Služba Božja, Makarska, 2003, 309-311 (na str. 309); Dinko Aračić, Karlo Balić, Služba Božja, Split, 2018, 16-18. 
fideističkim momentima). ${ }^{2}$ Louvainski je ontologizam u pojedinim njegovim aspektima Crkva osudila 1855., 1861. i 1866. ${ }^{3}$ Obrat prema neotomizmu na Katoličkom se sveučilištu u Louvainu intenzivira osamdesetih godina XIX. st., bivajući u institucionalnom pogledu dovršen godine 1889. osnutkom Višeg filozofskog instituta (Institut supérieur de philosophie). ${ }^{4}$ Pod vodstvom svoga osnivača Désiréa Josepha Merciera Institut vrlo brzo postaje međunarodno ugledan centar neotomističke misli. ${ }^{5}$ Louvainski neotomisti gaje duh otvorenosti prema modernoj znanosti i filozofiji, prožet kako spremnošću na korekciju pojedinih tomističkih teza gdje god se to pokaže potrebnim, tako i vjerom $u$ temeljna tomistička načela, $\mathrm{tj}$. vjerom da potrebe za njihovom korekcijom neće biti. ${ }^{6} \mathrm{~K}$ tome, louvainski neoto-

2 Usp. Joseph Louis Perrier, The Revival of Scholastic Philosophy in the Nineteenth Century, The Columbia University Press, New York, 1909, 215; Leonard E. Boyle, A Remembrance of Pope Leo XIII: The Encyclical Aeterni Patris, u: Victor B. Brezik (ur.), One Hundred Years of Thomism. Aeterni Patris and Afterwards. A Symposium, Center for Thomistic Studies, University of St. Thomas, Houston, Texas, 1981, 7-22 (na str. 12-13); Gerald A. McCool, Nighteenth-Century Scholasticism. The Search for a Unitary Method, Fordham University Press, New York, 1989, 113114, 125-128. O ontologizmu usp. George M. Sauvage, Ontologism, u: Charles G. Herbermann, Edward A. Pace, Condé B. Pallen, Thomas J. Shahan i John J. Wynne (ur.), The Catholic Encyclopedia, sv. XI, The Encyclopedia Press, New York, 1913, 257-258; P. J. Fitzpatrick, Neoscholasticism, u: Norman Kretzmann, Anthony Kenny i Jan Pinborg (ur.), The Cambridge History of Later Mediaval Philosophy, Cambridge University Press, Cambridge, New York, Melbourne, 1982, 838-852 (na str. 844-846); G. A. McCool, Nighteenth-Century Scholasticism, 113135, 147, 227. O tradicionalizmu usp. George M. Sauvage, Traditionalism, u: The Catholic Encyclopedia, sv. XV, 13-14; P. J. Fitzpatrick, Neoscholasticism, 838840; G. A. McCool, Nighteenth-Century Scholasticism, 37-58. O fideizmu usp. George M. Sauvage, Fideism, u: The Catholic Encyclopedia, sv. VI, 68-69; P. J. Fitzpatrick, Neoscholasticism, 839-840.

3 Usp. J. L. Perrier, The Revival of Scholastic Philosophy in the Nineteenth Century, 215; G. M. Sauvage, Ontologism; P. J. Fitzpatrick, Neoscholasticism, 844-846; G. A. McCool, Nighteenth-Century Scholasticism, 130-132.

4 Usp. J. L. Perrier, The Revival of Scholastic Philosophy in the Nineteenth Century, 216, 217-218; Maurice De Wulf, Scholasticism Old and New: An Introduction to Scholastic Philosophy Medieval and Modern, M. H. Gill and Son, Dublin, 1907., 264-268; Institut supériere de philosophie: A propos / L'institut / Historique, na mrežnim stranicama: Universite catholique de Louvain: Instituts de recherche, <https://uclouvain.be/fr/instituts-recherche/isp/historique.html> (pristupljeno 12. rujna 2019.).

5 Usp. J. L. Perrier, The Revival of Scholastic Philosophy in the Nineteenth Century, 40, 168-169, 182-183, 217-223.

$6 \quad$ Usp. J. L. Perrier, The Revival of Scholastic Philosophy in the Nineteenth Century, 168, 182-183, 217-223; M. De Wulf, Neo-Scholasticism, u: The Catholic Encyclopedia, sv. X, 746-749 (na str. 746-748); Ralph Del Colle, NeoScholasticism, u: David Fergusson (ur.), The Blackwell Companion to NineteenthCentury Theology, Wiley-Blackwell, Malden, Oxford, 2010., 375-394 (na str. 381); 
mizam njeguje i povijesni pristup. ${ }^{7}$ Naročito zaslugom Mauricea de Wulfa louvainski će Institut znatno pridonijeti sve ozbiljnijem istraživanju povijesti skolastičke filozofije (od samih njezinih početaka naovamo). ${ }^{8}$ Ta će istraživanja u mnogom pogledu promijeniti dotad uvriježen pojam o skolastici, očitujući postupno sve jasnije njezinu unutrašnju raznolikost i složenost. Louvainski će neotomisti tako, uz mercierovsku otvorenost prema modernoj filozofiji i znanosti, sa sve boljim poznavanjem povijesti skolastičke filozofije pokazivati i sve veću otvorenost i poštovanje prema raznim njezinim tradicijama, bilo tomističkim (poput suarezijanizma), bilo netomističkim (poput škotizma). ${ }^{9}$

To je dakle okruženje u kojem sazrijeva dvadesetih godina prošloga stoljeća mladi teolog i filozof fra Karlo Balić. U tom okruženju nalazi on mjesta za proučavanje filozofskog i teološkog, posebno mariološkog, opusa Ivana Dunsa Škota, ${ }^{10}$ što ce postati temom kojoj će posvetiti gotovo svu svoju znanstvenu karijeru. To je ujedno okruženje u kojem će on formirati i svoje temeljne neoskolastičke nazore: u prvom redu, povijesni (a ne spekulativni) pristup i otvorenost, kako prema modernoj filozofiji i znanosti, tako i prema raznim skolastičkim tradicijama (od franjevačke, škotističke, do tomističke, u raznim njezinim varijantama).

Ti temeljni Balićevi neoskolastički nazori, onako kako su eksplicirani (makar i fragmentarno, prigodice) u nekim njegovim radovima prema sredini prošloga stoljeća (primjerom, u njegovoj polemici s Hijacintom Boškovićem, u kojoj se okomljuje posebno na pantomizam), tema su koju istražujem u ovom radu. Namjera mi je iščitati iz tih fragmentarnih i sporadičnih iskaza cjelinu Balićeva pristupa, od pojedinih temeljnih načela što ga sustavljaju usustavljuju do konkretnog povijesnog okruženja u kojem je formiran, ne istražujući pritom način na koji je Balić primijenio ta načela u pojedinim svojim znanstvenoistraživačkim pothvatima (primjerice, u pripremi kritičkog izdanja Škotovih djela) i ne upuštajući se u evaluaciju, pogotovo pak ne arbitrirajući između Balićeva i Boškovićeva pristupa.

Bernard McGinn, Thomas Aquinas's Summa theologiae: A Biography, Princeton University Press, Princeton, Oxford, 2014., 177-178.

7 Usp. J. L: Perrier, The Revival of Scholastic Philosophy in the Nineteenth Century, 221-222; M. De Wulf, Neo-Scholasticism, 747; Del Colle, Neo-Scholasticism, 381.

8 Usp. J. L. Perrier, The Revival of Scholastic Philosophy in the Nineteenth Century, 221-222; M. De Wulf, Scholasticism..., 276-282; Del Colle, Neo-Scholasticism, 381.

$9 \quad$ Usp. M. De Wulf, Neo-Scholasticism, 746.

10 Usp. V. Kapitanović, Fra Karlo Balić, medievalist i mariolog, 256-257; D. Aračić, Karlo Balić, 16-18. 


\section{IN DUBIIS LIBERTAS!}

Pantomisti tvrde da je Crkva, posebno enciklikom Aeterni Patris pape Lava XIII. godine 1879., ${ }^{11}$ proglasila tomizam svojim službenim naukom i istinom i da, u skladu s tim, treba odbaciti i osuditi sve što se $\mathrm{s}$ tomizmom kosi. ${ }^{12}$

Pantomizam je u Hrvatskoj zastupao najizrazitije Hijacint Bošković, posebno u svome „Predgovoru“ hrvatskom izdanju Maritainova Anđeoskog naučitelja. ${ }^{13}$ Tom je prigodom Bošković kritizirao nastojanja oko obnove škotizma, posebno Prvi kongres franjevačkih slavenskih profesora, održan u Zagrebu od 25. do 29. rujna 1935., ${ }^{14}$ na što je reagirao Balić dvama opsežnim polemičkim člancima, objavljenima u Bogoslovskoj smotri 1937. i 1938., pretiskanima potom u zasebnom izdanju 1938. g. pod naslovom Sv. Toma Akvinski $i$ drugi naučitelji. ${ }^{15}$ Boškovićev odgovor na te članke uslijedio je tek za dvije godine, ${ }^{16}$ na što je Balić reagirao novim opsežnim člankom, objavljenim ovaj put u Novoj reviji, pretiskanim potom u zasebnom izdanju 1941. g. pod naslovom Tomizam u svijetlu naučne i nenaučne kritike. ${ }^{17}$

11 Lav XIII, Aeterni Patris, u: Acta Sanctae Sedis XII (1879.), 97-115.

12 Usp. Karlo Balić, Sv. Toma Akvinski i drugi naučitelji, Zagreb, 1938., 1-3; Karlo Balić, Tomizam u svijetlu naučne i nenaučne kritike, Franjevačka visoka bogoslovna škola u Makarskoj, Šibenik, 1941., 1-5, 25.

13 Hijacint Bošković, Predgovor, u: Jacques Maritain, Anđeoski naučitelj, Naklada Istina, Zagreb, 1936., 7-37 (na str. 16-20, 26-30, 35-36); Hijacint Bošković, Predgovor prvome izdanju, u: Jacques Maritain, Anđeoski naučitelj. Životno djelo sv. Tome Akvinskog, Zadruga Eneagram, Zagreb, 2011., 7-32 (na str. 14-18, 23-27, 31-32); Hijacint Bošković, Albert Veliki, Naklada Istina, Zagreb, 1932.; Hijacint Bošković, Sv. stolica o sv. Tomi, Bogoslovska smotra, 28 (1940.) 1, 17-56; Hijacint Bošković, Sv. Toma Akvinski i Duns Skot, Naklada Istina, Zagreb, 1940.

14 Usp. H. Bošković, Predgovor, 9-14, 20-23, 28, 33-34. H. Bošković, Predgovor prvome izdanju, 9-13, 18-21, 25, 29-30.

15 Karlo Balić, Sv. Toma Akvinski i drugi naučitelji, Bogoslovska smotra, 25 (1937.) 1-4, 47-74, 133-160, 261-290, 373-388; Karlo Balić, Crkveni auktoritet prema tomizmu i drugim katoličkim školama, Bogoslovska smotra, 26 (1938.) 1-4, 81-92, 180-193, 255-282, 375-392.

16 H. Bošković, Sv. stolica o sv. Tomi; H. Bošković, Sv. Toma Akvinski i Duns Scot.

17 Karlo Balić, Još o “naučnoj” metodi O. H. Boškovića, Nova revija, 19 (1940.) 2-6, 126-153, 224-268, 400-424; K. Balić, Tomizam u suijetlu naučne i nenaučne kritike. O polemici između Balića i Boškovića usp. Ivan Bekavac Basić, Polemika između Karla Balića i Hijacinta Boškovića: povod i ishod, u: Josip B. Percan (ur.), Hrvatski škotizam XX. stoljeća. Zbornik radova znanstvenog skupa (Zagreb - Katuni - Split, 27-29. V. 2008.), Pontificia Academia Mariana Internationalis, Zbornik Kačić, Brat Franjo, Rim, Sinj, Zagreb, 2011., 253-276; Daniel Miščin, Hijacint Bošković - promicatelj tomizma, u: Hijacint Bošković, Suvremenost tomističke baštine. Rasprave i članci, Glas Koncila, Zagreb, 2011., 7-42 (na str. 34-40). 
U cjelini, Balićeva kritika pantomizma počiva na načelu intelektualne slobode (u okvirima objavljenih i propisanih istina katoličke vjere i morala). Balić naime ističe da Katolička crkva dijeli istinu od mnijenja. Istinu utvrđuje Crkveno učiteljstvo temeljem objave. Utvrđene su istine neupitne, svete, dogme. Tome nasuprot, mnijenja se odnose na sve ono što istinom (dogmama) nije definirano. Sistemi (poput tomizma ili škotizma) nisu istina, nego mnijenja - točnije, to su sustavi mnijenja, vjerovanja, koji, da bi bili odobreni od Crkvenog učiteljstva, moraju biti u skladu s istinom, s dogmama, tj. sa svetom vjerom, ispravno je shvaćati i uspješno je braniti od krivovjerja, hereze. ${ }^{18}$

Pritom, Crkva definira dogme, ali ne i mnijenja (sisteme), i u pogledu definiranih dogmi zahtijeva jedinstvo, dok u pogledu sistemā dopušta intelektualnu slobodu i razlike. Svaki katolik dakle, s jedne strane, dužan je držati se definiranih istina vjere, s druge pak strane, u pogledu svega što svetom vjerom nije definirano, slobodan je iznijeti i braniti vlastito mnijenje. Crkva dakle ne nalaže mnijenje kao utvrđenu istinu i ne proglašava sistem dogmom, bilo da je riječ o tomizmu ili škotizmu ili kojem drugom sistemu, nego naprotiv dijeli sistem od istine (dogme) i, u skladu s tim, ne postavlja jedan sistem normom za sve ostale. Upravo suprotno, kad je o mnijenjima riječ, Crkva poštuje i štiti slobodu raspravljanja i drži natjecanje među različitim sistemima plodonosnim, prepoznaje u njemu znak svoje vitalnosti, preduvjet i jamstvo svoga napretka. ${ }^{19}$

Dva međusobno oprečna mnijenja ili sistema doista ne mogu biti oba istinita, ali zato mogu biti oba podjednako pouzdana (vjerojatna). Naravno, može biti i jedan (znatno ili neznatno) pouzdaniji od drugoga. Pritom, pouzdanost nije isto što i sigurnost. Sigurnost definitivno isključuje opreku kao neistinitu. Što god se protivi sigurnoj, utvrđenoj istini, neistinito je. Pouzdanost međutim ne isključuje

18 Usp. Karlo Balić, Značenje povjesnog proučavanja skolastične teologije i filozofije u naše doba, u: Collectanea Franciscana Slavica. Acta congressuum professoruum complectentia. Vol. I: Acta primi congressus - Zagrabiae 25-29 Sept. 1935, Šibenik, 1937., 117-136 (na str. 132); Balić, Sv. Toma Akvinski..., 1-2, 18-19, 110-111, 113-119; Karlo Balić, Što je skolastika?, Nova revija, 17 (1938.), 1-2, 55.

19 Usp. Karlo Balić, Povijesno proučavanje skolastične teologije i filozofije u naše doba, Bogoslouska smotra, 23 (1935.) 4, 401-425 (na str. 416-417); K. Balić, Sv. Toma Akvinski..., 1-2, 18-19, 110-111, 113-119; K. Balić, Što je skolastika?, 55; Karlo Balić, Skotistična škola u prošlosti i sadašnjosti, u: Collectanea Franciscana Slavica. Acta congressuum professorum complectentia. Vol. 1: Acta primi congressus - Zagrabiae, 25-29 Sept. 1935, Šibenik, 1937., 3-54 (na str. 52-54); K. Balić, Značenje povijesnog proučavanja..., 132; K. Balić, Tomizam..., 62-65. Primijetimo da istu slobodu (u okvirima objavljenih i propisanih istina katoličke vjere i morala) zagovara i Barac. Usp. Fran Barac, O modernoj katoličkoj apologetici, Požega, 1907., 75-76. 
opreku kao definitivno neistinitu, nego je čini tek manje vjerojatnom. Crkva stoga, preporučujući jedan sistem, ne odbacuje druge sisteme kao definitivno neistinite, nego ih samo proglašava manje pouzdanima od preporučenoga sistema. Dapače, ta se preporuka može pokazati i privremenom - s vremenom naime neki od nepreporučenih sistema može se pokazati, u svjetlu novih istraživanja i argumenata, pouzdanijim od preporučenoga sistema. U takvim situacijama Crkva je slobodna revidirati svoju preporuku. Drugim riječima, preporuka je uvijek uvjetna i ne ukida slobodu argumentiranja u prilog nepreporučenim mnijenjima ili sistemima. ${ }^{20}$

Preporučujući tomizam (iznad drugih sistema), posebno u enciklici Aeterni Patris, Crkva dakle ne ukida slobodu argumentiranja u prilog škotizmu, augustinizmu ili bilo kojem drugom filozofskom sistemu sukladnu objavljenim i propisanim istinama katoličke vjere i morala. Jedinstvo (bez razlika) Crkva nalaže samo kad je riječ o dogmama. U svemu ostalome ona dopušta slobodu, potičući ujedno na ljubav i zajedništvo u razlikama. Ukratko: „In necessariis unitas, in dubiis libertas, in omnibus caritas!" 21

\section{INTEGRALNA SKOLASTIKA}

Načelo intelektualne slobode $u$ pogledu svega dogmom nedefinirana nije tek temeljno načelo Balićeve kritike pantomizma nego i kontekst, okvir u pozadini njegova integralnoskolastičkog shvaćanja papinske enciklike Aeterni Patris. Budući da istinom proglašava samo dogme, ne i sisteme, Crkva nije tom enciklikom proglasila tomizam istinitim i samim tim odbacila druge sisteme, $u$ čemu god se s tomizmom ne slažu, nego je naprotiv Aeterni Patris tek preporuka, koja daje prednost skolastičkim sistemima, među kojima

20 Usp. K. Balić, Skotistična škola..., 37-38; K. Balić, Sv. Toma Akvinski..., 92-93, 103-104, 123-127. Izrijekom je ovaj stav potvrđen 1998. u enciklici Ivana Pavla II. Fides et ratio: „Crkva ne izlaže svoju vlastitu filozofiju niti preporuča bilo koju pojedinačnu filozofiju na štetu drugih.“ Ivan Pavao II, Fides et ratio, Kršćanska sadašnjost, Zagreb, 1999., 72; Acta Apostolicae Sedis 91, 1999., 44.

21 Usp. K. Balić, Sv. Toma Akvinski..., 139-140. Usp. također Pavo Barišić, Karlo Balić i aktualnost filozofske predaje, u: Marko Babić (ur.), Aktualnost predaje. Zbornik radova međunarodnoga znanstvenog skupa prigodom 100. obljetnice rođenja fra Karla Balića (Split, 06. XI. 1999.), Služba Božja, Makarska, 2003., 33-43 (na str. 34); Barbara Ćuk, Ivan Duns Skot i skotizam u hrvatskoj periodici prve polovice 20. stoljeća, Bogoslouska smotra, 80 (2010.) 4, 1105-1132 (na str. 11251127); Ivan Macut, Hrvatska filozofija od obnove zagrebačkog Sveučilišta 1874. do osnutka Nezavisne države Hrvatske 1941, Franjevačka provincija Presvetog Otkupitelja - Služba Božja, Split, 2018., 386-387. 
posebno tomizmu, ali pritom ne odbacuje druge sisteme (sukladne istinama katoličke vjere i morala) - dapače, Aeterni Patris ne govori u neupitno pozitivnu tonu samo o skolastici (ili tomizmu) nego i o patristici. U tom smislu, Balić drži da je enciklikom Aeterni Patris preporučena cijela skolastika, a posebno tomizam, pri čemu nije odbačena nijedna filozofija sukladna istinama katoličke vjere i morala. Iste se preporuke Crkva, prema Baliću, dosljedno drži i u nizu drugih svojih dokumenata s kraja XIX. i na početku XX. st. ${ }^{22}$

Skolastiku pritom Balić shvaća okvirno kao skup pozicija formiranih posebno tijekom XIII. i XIV. st. u nastojanju da se objavljene istine katoličke vjere i morala što sustavnije protumače, razrade i obrane primjenom osnovnih pojmova i načela grčke filozofije, posebno Aristotelove - primjerom, primjenom pojmovnog para materija-forma ili supstancija-akcidencija, akt-potencija itd. ${ }^{23}$ Te su se pozicije u kasnijim stoljećima dodatno razvijale, bivajući nerijetko razrađene i u smjeru pojedinih varijanti - tako se, primjerom, na prijelazu iz XVI. u XVII. st. javlja suarezijanizam kao varijanta tomizma.

Neoskolastički pokret dakle obuhvaćao bi obnovu svih tih pozicija, a ne samo tomizma. Unutar tog pokreta bilo bi mjesta i za obnovu škotizma ili augustinizma itd., a ne samo za obnovu tomizma. Balićeva je koncepcija (u okviru svega sukladna istinama katoličke vjere i morala) integralistička, a ne ekskluzivistička. ${ }^{24}$

\section{IRENEJSKI ARGUMENT}

Među pojedinim Balićevim argumentima protiv pantomizma ističe se onaj irenejski, koji gađa pantomističku uskoumnost. Onima naime koji su u počecima kršćanstva tvrdili da je od svih apostola

22 Usp. K. Balić, Skotistična škola..., 21-22; K. Balić, Sv. Toma Akvinski..., 103146; K. Balić, Što je skolastika?, 53.

23 Usp. K. Balić, Što je skolastika?, 55, 59-65. Usp. također Barbara Ćuk, Karlo Balić: integralna skolastika, u: Ivan Šestak, Josip Oslić i Anto Gavrić (ur.), Prilozi o hrvatskoj neoskolastici, Filozofsko-teološki institut Družbe Isusove u Zagrebu, Zagreb, 2014., 45-50 (na str. 48-49).

24 Usp. K. Balić, Skotistična škola..., 6, 7, 52-54; K. Balić, Značenje povijesnog proučavanja..., 119; K. Balić, Sv. Toma Akvinski..., 103-146; K. Balić, Što je skolastika?, 53; K. Balić, Tomizam..., 87-89. Usp. također M. De Wulf, NeoScholasticism. O Balićevoj integralnoj skolastici usp. Krsto Kržanić, Dr. o. Karlo Balić i integralna skolastika, Kačić, 3 (1970.), 35-46 (na str. 35-36); Barišić, Karlo Balić i aktualnost filozofske predaje, 33-34, 38-39; Josip Oslić, Vjera i um. Neoskolastički i suvremeni pristupi. Hrvatsko filozofsko društvo, Zagreb, 2004., 21, 186, 221-225; I. Ćuk, Ivan Duns Skot..., 1108-1109, 1123, 1124; I. Ćuk, Karlo Balić..., 48-50; I. Macut, Hrvatska filozofija, 375; D. Aračić, Karlo Balić, 33-34. 
samo sv. Pavao upoznao istinu (dakle, marcionistima) sveti je Irenej odgovorio kako Bog nije tako siromašan da bi imao samo jednog apostola. Na isti način, prvih desetljeća prošloga stoljeća pantomistima odgovaraju razni katolički učenjaci u raznim katoličkim časopisima kako Bog nije tako siromašan da bi imao samo sv. Tomu. ${ }^{25}$

Premda neizrečen, irenejski se argument osjeća i u Balićevu suprotstavljanju onima koji drže da je skolastika riješila sve probleme i opovrgnula sve zablude, pa i one kasnije, za koje nije ni znala - kao da bi, recimo, Toma unaprijed pobio i Lockea i Kanta i Spencera i Comtea i Bergsona itd. i kao da bi, dakle, skolastika bila vječna filozofija, philosophia perennis, koja je proniknula svu istinu. Takve filozofije, prema Baliću, ne može biti. Pod istinom naime Balić misli $\mathrm{u}$ prvom redu na objavljenu istinu, u svome otajstvu uzvišenu, nadnaravnu, koju iz svoje ovozemne perspektive pokušavamo ovom ili onom filozofijom spoznati što jasnije i obuhvatnije, ali u tome nećemo nikad u potpunosti uspjeti, jednostavno zato što iz ovozemne, naravne perspektive nije moguće sagledati cjelinu nadnaravne stvarnosti. Nema dakle filozofije koja bi mogla proniknuti svu objavljenu istinu, u svem njezinu uzvišenu otajstvu, i u tom smislu biti apsolutan i definitivan izraz katolicizma. ${ }^{26}$ Objavljena istina jednostavno nije toliko siromašna da bi mogla biti iscrpljena ovom ili onom pojedinom filozofijom.

Premda neizrečen, irenejski se argument osjeća i u Balićevu razmatranju odnosa između pojedine filozofije i sveukupna čovjekova spoznajnog potencijala. Balić naime ističe da tijekom povijesti mnoge filozofije istražuju (objavljenu) istinu, svaka iz svoje perspektive, $u$ okviru svojih temeljnih principa i svoga sustava, cjeline, i svaka primarno vezana uz svoje vrijeme, tj. uz konkretno povijesno okruženje u kojem je nastala i potvrdila svoju vrijednost, koliku-toli$\mathrm{ku}$, u srazu s drugim tada aktualnim filozofijama. Svaka je filozofija dakle posebna, kako u svome vremenu, sinkronijski, spram drugih tada aktualnih filozofija, tako i tijekom povijesti, dijakronijski, spram prijašnjih i kasnijih filozofija. Balićev je stav da nema sinteze koja bi mogla u jednom sustavu obuhvatiti svu tu posebnost. Čovjekov se spoznajni potencijal realizira uvijek $u$ konkretnim povijesnim prilikama u kojima se nađe. Budući da se te prilike mijenjaju (pa ih

25 Usp. K. Balić, Sv. Toma Akvinski..., 2, 145. Sv. Irenej, Contra haereses libriquinque, u: J.-P. Migne (ur.), Patrologiae cursus completus. Patrologiae Graecae tomus VII. Pars prior, Brepols, Turnhout, 1857., 911 (lib. III, cap. XIII). Usp. također K. Balić, Skotistična škola..., 53; Balić, Tomizam..., 88-89. Usp. također P. Barišić, Karlo Balić i aktualnost filozofske predaje, 34; I. Macut, Hrvatska filozofija, 380. 
zato i zovemo povijesnima), slijedi da je čovjekov spoznajni potencijal do samog konca povijesti konstantno otvoren prema novome, nadolazećem, još uvijek nepoznatome. Drugim riječima, ni u kojem trenutku, do samog konca povijesti, ne možemo znati čemu će se sve naša spoznaja otvoriti, u kakvim cee sve povijesnim okolnostima formirati svoje sisteme. Možemo dakle samo pogriješiti držeći neki sistem sintezom svega našega uopće mogućega znanja. Svaki je sistem poseban, vezan primarno uz svoje vrijeme, i hoćemo li potvrditi njegovu vrijednost $u$ nekom drugom, novom vremenu, moramo ga otvoriti problemima i potrebama što ih nameće to (novo) vrijeme, dopuštajući pritom mogućnost da se u tom novom vremenu pojavi i neki novi sistem, koji će ponuditi svoj odgovor na te nove probleme i potrebe, možda i bolji od onog što ga nudi dotični stari sistem. Ili će se možda pojaviti i više takvih novih sistema. U svojoj otvorenosti prema novome čovjekov je spoznajni potencijal dakle, irenejski rečeno, jednostavno prebogat da bismo ga mogli obuhvatiti tek jednim sistemom, jednom filozofijom, apsolutnom i definitivnom, za sva vremena i sve naraštaje. Nema filozofije, koliko god da je sadržajno bogata i sustavno razrađena, koja bi mogla iscrpsti sav čovjekov spoznajni potencijal, u svoj njegovoj punini, životnosti i plodnosti. ${ }^{27}$ Ukratko, ne samo da Bog nije toliko siromašan da bi imao samo sv. Tomu Akvinca nego ni objavljena istina nije toliko siromašna da bi mogla biti iskazana tek nekom filozofijom, makar i tomističkom - dapače, ni čovjekov (ovozemni) spoznajni potencijal nije toliko siromašan da bi mogao biti iscrpljen tek nekom od filozofija.

\section{POVIJESNI PRISTUP}

Balić preferira povijesni pristup, nasuprot spekulativnome. ${ }^{28}$

Svaka je filozofija primarno odgovor na probleme i potrebe vremena u kojem je nastala. Skolastički su sistemi primarno odgovor na probleme i potrebe trinaestoga i četrnaestoga stoljeća. Moderna je filozofija primarno odgovor na probleme i potrebe modernih povijesnih okolnosti, bitno drukčijih od onih srednjovjekovnih. (Pritom, jasno, sa svakim odgovorom možemo, ali i ne moramo biti zadovoljni.) Drugim riječima, skolastičke sisteme ne možemo sasvim jasno shvatiti u okviru modernih problema i potreba, kao što ni modernu

27 Usp. K. Balić, Što je skolastika?, 54-55, 65. Usp. također Ćuk, Karlo Balić..., 47-48.

28 Usp. K. Balić, Skotistična škola..., 53-54. 
filozofiju ne možemo ispravno shvatiti u kontekstu srednjovjekovnih (ili antičkih) problema. Potrebno je dakle uživjeti se u dotično vrijeme, kulturu, dobro je upoznati i istražiti, kako bi nam bio jasan pravi smisao problema i potreba što ih je ona nametnula, a u tom okviru onda i pravi smisao odgovora što ih je na te probleme i potrebe dotična filozofija dala. ${ }^{29}$

Ukratko, izvan pravog povijesnog konteksta nema ni pravog razumijevanja pojedine filozofije. Balićevim riječima, u konkretnom slučaju skolastičke filozofije: „Ova cjelina, skolastična sinteza, nastala je $\mathrm{u}$ vremenu, $\mathrm{u}$ prostoru, i stoga je treba promatrati i proučavati ne kao nešto izvanvremenskog, apsolutnog, nego u njenom kontekstu, u atmosferi sveučilišnog života 13. i 14. vijeka."30

Svoj doprinos neoskolastičkoj filozofiji Balić traži primarno u istraživanju povijesti srednjovjekovne filozofije, usredotočujući se posebno na opus Ivana Dunsa Škota. Tim istraživanjem nastoji on u prvom redu ispraviti neopravdano negativnu sliku kako o Škotu, tako i o skolastici, koju njegovo vrijeme baštini od humanizma, renesanse i prosvjetiteljstva. ${ }^{31}$ Balićeva se istraživanja Škota i škotizma temelje na dosljedno provedenu kritičkom pristupu. ${ }^{32}$ Balić obilazi razne knjižnice i arhive diljem Europe, kako one velike i znamenite tako i one male, zabitne, kako one samostanske ili biskupijske, unutar Crkve, tako i one građanske, otkrivajući u njima ne samo nove rukopise već poznatih djela nego i nova djela, dotad sasvim nepoznata. ${ }^{33}$ Besprijekornom znanstvenom strogošću i minucioznošću detektira on pritom pogrešne atribucije i razrješava bezbrojne nedoumice što ih pronađeni rukopisi izazivaju (pojedinim svojim umeci-

29 Usp. K. Balić, Značenje povijesnog proučavanja..., 118, 120, 134. Usp. također Maurice De Wulf, Western Philosophy and Theology in the Thirteenth Century, The Harvard Theological Review, 11 (1918.), 409-432 (na str. 410).

30 Usp. K. Balić, Povijesno proučavanje..., 410.

31 Usp. K. Balić, Povijesno proučavanje..., 409-412; K. Balić, Skotistična škola..., 22-39; K. Balić, Značenje povijesnog proučavanja..., 118, 119-120, 122. Istom cilju stremi i De Wulf. Usp. M. De Wulf, Scholasticism..., 276-278; M. De Wulf, Western Philosophy..., 9-11, 420, 430-432. Usp. također I. Ćuk, Ivan Duns Skot..., 1109-1111, 1121-1125.

32 Kritički pristup istraživanju Škotova djela Balić ukratko opisuje svojim djelima: Povijesno proučavanje..., 420-425; Skotistična škola..., 39-52; Značenje povijesnog proučavanja..., 134 .

33 Usp. G. H. Jurišić, Sedamdeseta godišnjica života i rada fra Karla Balića, 8-12; Dinko Aračić, Fra Karlo Balić i njegov rimski krug, u: Luka Tomašević (ur.), Gospodin vam dao mir, Franjevačka provincija Presvetog Otkupitelja, Split, 2017., 507-514 (na str. 507); I. Macut, Hrvatska filozofija, 375-376, 378; D. Aračić, Karlo Balić, 17, 31. 
ma, dodacima, bilješkama, ispravcima itd.). ${ }^{34} \mathrm{~K}$ tome, ne ustručava se insistirati na znanstveno utvrđenim činjenicama, koliko god neugodne bile. ${ }^{35}$ Ali se pritom ne zadržava na golim činjenicama, nego sve vrijeme ima na pameti temeljno načelo povijesnog pristupa: sam tekst nije dostatan - potrebno ga je naime na ispravan način razumjeti, a to nije moguće bez dobra poznavanja njegova konteksta, povijesnog okruženja u kojem je nastao i u kojem je definirao svoju svrhu, predmet i metodu. ${ }^{36}$ To konkretno znači da je Škotovu misao moguće ispravno shvatiti samo u kontekstu filozofskih previranja u XIII. i XIV. st. i da je ta previranja, skolastiku samu (u XIII. i XIV. st.), moguće ispravno shvatiti samo u širem kontekstu dotične epohe (u kojoj je ona i nastala), imajući dakle na pameti u prvom redu osnovnu činjenicu da je u to vrijeme sav život, javni i privatni, bio prožet kršćanskim (katoličkim) svjetonazorom - kako filozofija, tako i umjetnost, politika itd. ${ }^{37}$

Balićev je trud urodio plodom. ${ }^{38}$ Predodžba o Ivanu Dunsu Škotu, koga su još početkom XX. st. držali uglavnom rušiteljem tomizma i pretečom modernoga skepticizma, agnosticizma i pozitivizma, stubokom je izmijenjena. Potvrđuju to i riječi pape Pavla VI: „Uz veličanstvenu katedralu sv. Tome Akvinskoga, među drugima diže se i ona, svake časti dostojna - iako različita po obujmu i građi - koju je Ivan Duns podigao visoko prema nebu te svojim žarkim spekulativnim genijem postavio je na čvrste temelje i ukrasio smionim tornjevima."39

34 Usp. G. H. Jurišić, Sedamdeseta godišnjica života i rada fra Karla Balića, 8-12; V. Kapitanović, Fra Karlo Balić..., 258, 260; D. Aračić, Fra Karlo Balić..., 507509, 512; D. Aračić, Karlo Balić, 17, 33-40.

35 Usp. Balić, Značenje povijesnog proučavanja..., 118, 127-134, 135; Balić, Tomizam..., 36-71. Usp. također V. Kapitanović, Fra Karlo Balić..., 257-258; Josip B. Percan, Balićev nastupni govor na Antonianumu godine 1933. u kontekstu tradicije hrvatskog škotizma XX. stoljeća, u: Hrvatski škotizam..., 235251 (na str. 235-236); D. Aračić, Fra Karlo Balić..., 507-508; I. Macut, Hrvatska filozofija, 372-373; D. Aračić, Karlo Balić, 18-19, 31-33.

36 Usp. K. Balić, Povijesno proučavanje..., 402-403, 417-420. Usp. također Barišić, Karlo Balić i aktualnost filozofske predaje, 35-38; I. Ćuk, Ivan Duns Skot..., 1108-1109, 1121-1124; D. Aračić, Karlo Balić, 35.

37 Usp. Balić, Što je skolastika?, 49. Usp. također M. De Wulf, Western Philosophy..., 420-423.

38 Naravno, treba pritom uvijek imati na pameti i doprinos Balićevih bliskih suradnika. Usp. o tom D. Aračić, Fra Karlo Balić...

39 D. Aračić, Karlo Balić, 142, 149. Usp. također Acta Apostolicae Sedis 58, 1966, 611. 


\section{TOMINIM STOPAMA}

U svome kratkom prikazu Barčeve pozicije Balić ističe načelo da Tomu treba slijediti u onom što je on činio u svoje vrijeme. ${ }^{40}$ Sam Barac to načelo - nazovimo ga načelom nasljedovanja Tomina čina ${ }^{41}$ - preuzima od Ollé-Laprunea. ${ }^{42}$ No što to načelo znači za Balića, možemo shvatiti samo istraživši Balićevo viđenje Tomina vremena i Tomine uloge u tom vremenu. Izložimo stoga ovdje, barem u osnovnim crtama, Balićevo shvaćanje Tomina vremena i Tomine uloge $u$ tom vremenu, kako bismo mogli shvatiti značenje što ga za Balića ima načelo nasljedovanja Tomina čina.

Nakon što se od sredine XII. st. javljaju prijevodi sve većeg broja Aristotelovih djela na latinski jezik, razni su se filozofi pri obrazlaganju svoga nauka znali na pojedinim mjestima poslužiti i ovim ili onim Aristotelovim argumentom, što još uvijek nije činilo njihovu filozofiju dominantno aristotelovskom. Tek s Albertom Velikim, a potom i Tomom Akvinskim stupa aristotelizam (u punom smislu te riječi) na filozofsku scenu srednjega vijeka, bivajući sustavno i cjelovito primijenjen na kršćanski nauk. ${ }^{43}$

Tijekom XIII. st. ni Crkveno učiteljstvo ni pojedini redovi (uključujući dobrim dijelom i dominikance) nisu gledali blagonaklono na pojavu i širenje aristotelizma (tomizma). S jedne strane, aristotelizam je bio izvorno poganska (starogrčka) filozofija, uvezena u kršćanski svijet iz jedne druge, inovjerne kulture (arapske), nasuprot augustinizmu, koji je u to vrijeme bio već odavno uvriježen među kršćanskim filozofima i teolozima. S druge strane, aristotelizam se u XIII. st. pojavio kao filozofija, profana znanost, odvojena od teologije, te je $\mathrm{u}$ tom smislu i napadan, sve dok nije uspio dokazati (upravo $\mathrm{u}$ tomizmu) i svoj kršćanski potencijal. Balić navodi mnoge osude aristotelizma (odnosno tomizma), kao i zabrane, bilo s razine Crkvenog učiteljstva, bilo unutar pojedinih redova. ${ }^{44}$

Filozofskim i teološkim raspravama u XIII. i XIV. st. dominira dakle konflikt između augustinizma i aristotelizma. Taj nam konflikt

$40 \quad$ Usp. K. Balić, Sv. Toma Akvinski..., 5-7.

41 Primijetimo da načelo nasljedovanja Tomina čina nije inkompatibilno s načelom nasljedovanja Tomina nauka, koliko god da se od njega bitno razlikuje.

42 Usp. F. Barac, O modernoj katoličkoj apologetici, 95-96. O burnoj polemici koju je izazvala ova Barčeva knjiga usp. Ivica Zvonar, Mons. dr. Fran Barac (1872.-1940.). Život $i$ djelo, Kršćanska sadašnjost, Zagreb, 2012., 42-44, 60-97; Ivica Zvonar, Dr. Fran Barac, Katolički bogoslovni fakultet Sveučilišta u Zagrebu, Kršćanska sadašnjost, Zagreb, 2016., 44-49.

43 Usp. K. Balić, Sv. Toma Akvinski..., 37-39.

44 Usp. K. Balić, Skotistična škola..., 6, 7; K. Balić, Sv. Toma Akvinski..., 37-45; K. Balić, Što je skolastika?, 59-60; K. Balić, Tomizam..., 4, 27-36, 43. 
ne može biti sasvim jasan u svoj svojoj žestini i ozbiljnosti, zanemarimo li činjenicu da u tom trenutku augustinizam već stoljećima uživa ugled najautentičnije kršćanske filozofije, dok aristotelizam biva - sasvim prirodno - percipiran kao nešto novo, što ne dolazi iz kršćanskoga svijeta, nego mu se tek pokušava nametnuti. Iz današnje perspektive, $s$ aristotelizmom odavno već prihvaćenim, dapače i dominantnim unutar kršćanske tradicije, mogao bi nam taj konflikt (između augustinizma i aristotelizma u XIII. i XIV. st.) izgledati tek kao unutarkršćanska razmirica (između dvije neprijeporno kršćanske tradicije), ali ne onakav kakav je doista bio: konflikt između dva svijeta, onog neprijeporno kršćanskog i onog poganskog i profanog, koji svoju kršćansku i teološku vrijednost tek nastoji dokazati.

U tom konfliktu tomisti su na koncu uspjeli dokazati kršćanski i teološki potencijal što ga u sebi krije Aristotelova filozofija te su samim time unijeli svježu krv u tadašnja teološka i filozofska razmatranja, preuzevši s vremenom i dominaciju, ali - s druge strane - nije ni augustinizam bio takvim rezultatom odbačen, nego je naprotiv potvrdio svoju vitalnost, koliko god da je dominaciju prepustio aristotelizmu (tomizmu). Teološka i filozofska misao bila je dakle u konačnom ishodu tog konflikta obogaćena jednim novim, bitno drukčijim pristupom (tomizmom), sačuvavši pritom i onaj tradicionalni pristup (augustinizam) - dapače, taj duh otvorenosti prema novome potaknuo je tijekom razvoja skolastičke misli daljnju pluralizaciju filozofske i teološke scene (povrh one s početka osnovne polarizacije između tomizma i augustinizma), o čemu svjedoči na poseban način pojava škotizma, već početkom XIV. st.

Što je dakle činio Toma (u svoje vrijeme)? U doktrinarnom pogledu zagovarao je aristotelizam i, primjenjujući ga na kršćanski nauk, formirao je sustav koji zovemo tomizmom. Iz povijesne perspektive, međutim, zagovarao je nešto novo, dapače, nešto pogansko i profano, u tom trenutku još uvijek odvojeno od kršćanske teologije, aristotelizam, te je na koncu ipak uspio, usprkos otporima (osudama i zabranama), demonstrirati vrijednost kojom taj poganski sustav može i te kako pridonijeti kršćanskoj teologiji, unijevši tako u tadašnju teološku i filozofsku misao svježinu i duh otvorenosti prema novome, širinu, koja će odlikovati skolastiku tog doba i nakon Tomine smrti. U povijesnom smislu dakle Tomin je životni pothvat upravo abrahamovski put $u$ nešto novo, bitno drukčije od već uvriježenoga, ${ }^{45}$ pri čemu, naravno, objavljene istine kršćanske

45 Abraham naime na samom početku povijesti spasenja napušta svoju zemlju, zavičaj, očinski dom, i kreće u krajeve dotad mu sasvim nepoznate, kako bi postao praocem novoga naroda, velika i blagoslovljena (usp. Post 12, 1-4). 
vjere i morala ostaju tim abrahamovskim pothvatom neugrožene: ${ }^{46}$ tomizam nije nova vjera, nego nov pristup istoj (kršćanskoj) vjeri, njezinim vječnim, nepromjenjivim istinama.

U skladu s tim, Tomu je danas moguće slijediti na dva načina: prvo, slijediti njegov nauk (svaku pojedinu njegovu tezu ili barem temeljna njegova načela), drugo, slijediti njegov čin, otvoriti se novome, modernome (novovjekovnoj filozofiji i znanosti), onako kako se i on sam u svoje vrijeme otvorio novome, aristotelizmu, ne odstupajući pritom od vječnih i nepromjenjivih istina katoličke vjere i morala.

Pritom se ta dva različita načina nasljedovanja Tome i tomizma međusobno ne isključuju. Moguće je naime otvarati se novome, u većoj ili manjoj mjeri, držeći se pritom temeljnih načela tomizma. Ali je isto tako moguće i sasvim zatvoriti vrata pred bilo čim novim i Tomu slijediti u strogo doktrinarnom smislu, držeći se isključivo njegovih teza. Konačno, moguće je Tomu slijediti i samo u njegovu činu, dakle, posve se otvoriti novome i, u doktrinarnom smislu, posve napustiti Tomin nauk. ${ }^{47}$

Tomizam danas ne može biti iznova nov, onako kako je nov bio u XIII. st., i baš zato, otvarajući se novome danas, onako kako se Toma otvarao novome u svoje vrijeme, slijedeći dakle ono što je on sam činio (u svoje vrijeme), mogli bismo se naposljetku naći i izvan tomizma, napustivši postupno ne samo pojedine njegove teze nego i sama temeljna njegova načela, zamijenivši ih nekim novim načelima, na kojima bismo onda gradili neku novu kršćansku filozofiju (kršćansku utoliko što se ni u čemu ne bi kosila s istinama vjere, nego bi ih naprotiv uspješno branila od krivovjerja). Takav ishod otvaranja novome ne možemo unaprijed isključiti. Otvaranje novome doista bi moglo rezultirati i nekom iz temelja novom kršćanskom filozofijom, koja bi mogla s vremenom i preuzeti dominaciju, ali bi pritom tomizam svejedno mogao potvrditi svoju vitalnost, onako kako je svoju vitalnost u XIII. i XIV. st. potvrdio augustinizam, opstavši, unatoč činjenici da više ne dominira. No u tom otvaranju

46 Kao što benediktinac ne napušta svoj samostan, zavjetujući se na stalnost mjesta (stabilitas loci), tako ni katolik (benediktinac ili koji drugi), koliko god da se u filozofiji upustio, poput Tome, upravo abrahamovski u nešto sasvim novo, ipak nikad ne napušta objavljene i propisane istine katoličke vjere i morala. I on je dakle vezan mjestom (stabilitas loci), od kojeg se ne odvaja. To je mjesto dogma, istina (objavljena i propisana), koja definira njegov katolički identitet. O zavjetu stalnosti mjesta usp. Gilbert Roger Hudleston, Western Monasticism, u: The Catholic Encyclopedia, sv. X, 472-476 (na str. 473-474).

47 Jasno je da takvu poziciju ne bismo mogli u doktrinarnom pogledu i dalje zvati tomizmom, ali nam upravo to govori da slijediti Tomu u njegovu činu, pristupu, barem načelno uključuje i mogućnost prevladavanja njegova nauka. 
prema novome moglo bi se dogoditi da tomizam i zadrži dominaciju, potvrdivši tako svoju vitalnost u još većoj mjeri. Ne može se dogoditi samo to da tomizam svoju vitalnost potvrdi zatvarajući se pred novim, modernim, $\mathrm{u}$ (vlastite) teze formulirane $\mathrm{u}$ nekom drugom povijesnom okruženju, kojeg više nema (recimo, u XIII. st., u jeku borbe $s$ augustinizmom, koje više nema). Da bi uopće bio u prilici potvrditi svoju vitalnost, tomizam se mora otvoriti modernim problemima i sučeliti se s modernim rješenjima tih problema, dopuštajući uvijek mogućnost da u tom otvaranju i sučeljavanju u konačnici možda i izgubi dominaciju koju je stekao u nekim drugim povijesnim okolnostima i potom je u katoličkom svijetu zadržao do danas. Abrahamovski rečeno, potrebno je napustiti sigurnost, zaštićenost, preuzeti rizik i ne pozivati se previše na preporuke dane možda i u bitno drukčijim povijesnim okolnostima, kakvih danas više nema. Balićevim riječima, krajnje zaoštreno: „U filozofiji apelirati na auktoritet, to znači - kukavičluk!"48

Ukratko, u okviru Balićeva shvaćanja filozofskih previranja u XIII. i XIV. st., slijediti Tomu u onom što je on činio u svoje vrijeme znači otvarati se novome, modernome, pa i po cijenu eventualnog napuštanja tomizma (odnosno skolastike) u smjeru neke iz temelja nove, netomističke (odnosno neskolastičke) katoličke filozofije. ${ }^{49}$

\section{ModernA FILOZOFIJA}

Na prvi pogled Balićev stav prema modernoj filozofiji nije dosljedan. S jedne strane, naime, Balić generalno uz novi vijek veže pad kako u vjerskom životu tako i u znanosti (filozofiji), i u tom smislu govori o žalosnim okolnostima i o modernim filozofskim zabludama (kartezijanizam, jansenizam, racionalizam, kriticizam, panteizam, pozitivizam). Moderno je doba obilježeno ne samo sumnjom u svrhunaravni red nego i sumnjom u same temelje filozofije, sama temeljna njezina načela. ${ }^{50}$

48 Usp. K. Balić, Tomizam..., 16, 20.

49 Nema indicija da bi potpuno napuštanje skolastike bilo konačni cilj Balićeva pristupa. Naprotiv, sasvim je jasno da Balić vjeruje kako potrebe za napuštanjem temeljnih skolastičkih načela neće biti (usp. npr. Balić, Značenje povijesnog proučavanja..., 136). To napuštanje samo je mogućnost koju ideja otvaranja modernoj znanosti i filozofiji u sebi načelno krije, ne i cilj tog otvaranja, niti neizbježan njegov ishod. Vjeru u temeljne skolastičke principe iskazuje i De Wulf (usp. M. De Wulf, Neo-Scholasticism). Ni Barac ne govori o napuštanju tih principa, nego, naprotiv, o preporodu tomizma, odnosno skolastike. Usp. F. Barac, O modernoj katoličkoj apologetici, 95-96.

50 Usp. K. Balić, Povijesno proučavanje..., 401; K. Balić, Sv. Toma Akvinski..., 103. 
S druge strane, međutim, Balić pozdravlja otvaranje skolastike toj istoj (zabludnoj!?) modernoj filozofiji. Pozdravlja tako Mercierov moderan filozofski pristup, sa spoznajnim problemom kao polazištem filozofskih istraživanja, i to formuliranim onako kako ga je formulirala moderna filozofija, posebno Kant. Pozdravlja dakle povezivanje tomizma (odnosno, skolastike) s modernom filozofijom i aktualnim problemima modernog čovjeka, pa i pod cijenu sumnje da to više nije tomizam (ni skolastika). ${ }^{51}$

$\mathrm{K}$ tome, Balić ističe (u pozitivnom smislu) i Barčevu poziciju: $\mathrm{s}$ pomoću naših znanosti (kojih u Tomino doba nije bilo), uključujući pritom i doprinos moderne filozofije, nasuprot izrazito negativnu pantomističkom stavu prema modernoj filozofiji (kao da ona nikakva doprinosa nije dala), izgraditi novu kršćansku filozofiju, kadru odgovoriti na aktualne filozofske i ine probleme modernog čovjeka. ${ }^{52}$ Smisao je enciklike Aeterni Patris, prema Barcu, nasljedovati Tomu $\mathrm{u}$ onom što je on činio (u svoje vrijeme), a ne nasljedovati ga u svakoj pojedinoj njegovoj tezi, ponavljajući ga (papagajski, kruto, beživotno) kao da je nepogrešiv, za sva vremena i sve naraštaje, u svim povijesnim okolnostima. ${ }^{53}$ Balić pozdravlja i kritički Barčev pristup skolastici, ističući posebno njegovu konstataciju da je ona u mnogome svome apriornom odgovoru pogriješila i da bi bolje bilo da je mjesto takvih odgovora skromno i ponizno priznala da ne zna. ${ }^{54}$

51 Usp. K. Balić, Sv. Toma Akvinski..., 8. Moguću sumnju u pogledu Mercierova tomizma ističe Karlo Grimm. Usp. Karlo Grimm, U spomen kardinala Deziderija Merciera, Bogoslouska smotra, 14 (1926.) 2, 191-197 (na str. 196).

52 Usp. K. Balić, Sv. Toma Akvinski..., 5-7. Barčevim riječima: „Jamačno apologet mora da se posluži zdravim rezultatima historičkih, filozofskih, prirodnih i socijalnih znanosti.“ F. Barac, O modernoj katoličkoj apologetici, 76. Ili: „Mi treba da govorimo ne samo jezikom Platona i Aristotela, nego i s pomoću moderne misli i modernih filozofskih pojmova." F. Barac, O modernoj katoličkoj apologetici, 76. Još jasnije: „Sve naše spoznaje natprirodnih istina osnivaju se na više manje podesnim poređenjima, kongruencijama, analogijama. Mi izričemo natprirodne istine nesavršenim ljudskim jezikom. Dogme se osvjetljuju i utvrđuju filozofijom Platona i Aristotela. Zar se u modernoj filozofiji ne bi dalo naći možda ljepših misli i zgodnijih pojmova, kojima bi se dale poznate vjerske istine bliže primaći ljudskom umu? Zar se u bolje upoznatoj prirodi ne bi moglo otkriti podesnijih analogija, nego što su one, koje su skolastici uzimali iz Aristotelove fizike?" F. Barac, O modernoj katoličkoj apologetici, 78-79.

53 Usp. F. Balić, Sv. Toma Akvinski..., 5-7; F. Barac, O modernoj katoličkoj apologetici, 95-96. Uputimo i na sljedeće Barčeve riječi (u vezi s nasljedovanjem Tomina čina): „Da je danas sv. Toma živ, bavio bi se on - kako se onda bavio sa Averroes-om, Siger de Brabant-om, Pierre Olive-om - sa Kantom, Spencer-om, Comte-om..." F. Barac, O modernoj katoličkoj apologetici, 97.

54 Usp. K. Balić, Sv. Toma Akvinski..., 5-7. Barčev poziv na skromnost posebno je oštro iskazan sljedećim riječima: „Znajmo biti čedni i ne težimo za tim, da znamo na sve dati točan odgovor. Nije moguće, da genij XIX. vijeka samo tlapi i sanja. 
I Zimmermannove zasluge Balić vidi prvenstveno u njegovu otvaranju modernoj filozofiji, pod Mercierovim i Geyserovim utjecajem. Temeljito proučivši peripatetičko-skolastičku filozofiju, Zimmermann je sučeljuje s raznim modernim filozofskim strujama, prihvaćajući pritom istinu gdje god je nađe - dakle, ne samo u skolastici, isključivo, nego možda i u modernoj filozofiji, pa i po cijenu eventualne sumnje (ili sumnjičenja) da takvim pristupom zapravo napušta tomizam (odnosno, skolastiku). ${ }^{55}$

Čini se dakle prilično jasnim da Balić pristaje uz one koji povezuju skolastiku s modernom filozofijom, i to onako kako to čine, primjerom, Mercier ili Zimmermann, preuzimajući modernu formulaciju pojedinih filozofskih problema, makar i po cijenu sumnje da tim načinom zapravo gube svoj tomistički, odnosno skolastički identitet. Ali je isto tako jasno da je Balićev stav o modernoj filozofiji generalno negativan.

Možemo stoga zaključiti da Balić ne pristaje generalno uz modernu filozofiju, nego je generalno drži zabludom, što mu međutim ne priječi u pojedinim modernim filozofskim uvidima i pristupima prepoznati vrijedan doprinos, na kojem bi i neoskolastika imala što nadograditi. Kao što je u XIII. i XIV. st. aristotelizam izgledao mnogima, ne bez ikakva razloga, upravo poganskim i s kršćanstvom nespojivim, pa je ipak, zahvaljujući posebno Tomi Akvinskome, dokazao svoj kršćanski potencijal i s vremenom postao dominantna tradicija kršćanske filozofije, tako i danas mnogi moderni filozofski pristupi, ne bez razloga, čine se, iz kršćanske perspektive, očitim zabludama, nepopravljivo sekularnima i s kršćanstvom nespojivima, ali to ipak ne mora značiti da u sebi ne kriju baš nikakav kršćanski potencijal, koji bi vrijedilo prepoznati i istražiti i omogućiti mu da na svoj način pridonese ispravnu tumačenju objavljenih istina i njihovoj obrani od krivovjerja, eventualno i daljnjoj njihovoj sustavnoj razradi.

Samo je na prvi pogled dakle Balićev stav prema modernoj filozofiji nedosljedan. Uistinu međutim, detaljnije razmotren, pokazuje se on u sebi sasvim konzistentnim. Premda modernu filozofiju drži generalno zabludom, Balić se priklanja onima koji skolastiku (ili tomizam) otvaraju pojedinim vrijednim modernim filozofskim uvidima i pristupima što u sebi kriju možda i znatan teološki potencijal.

Budimo uvjereni, da nijesmo mi jedini posjednici istine, $\mathrm{i}$ da istina, koju mi znamo, nije istina cijela cjelcata. Priznajmo dobro u protivnika: ma i bilo šarlatana, ima i čestitih radnika. Ima istine (prirodne) i kod drugih, ne samo u katolika!“ F. Barac, O modernoj katoličkoj apologetici, 96-97.

55 Usp. K. Balić, Sv. Toma Akvinski..., 7-9. Usp. također J. Oslić, Vjera i um. Neoskolastički i suvremeni pristupi, 221-223. 


\section{NOVA ET VETERA}

Revue Néo-Scolastique, časopis Louvainskoga filozofskog društva (Société Philosophique de Louvain), pokrenut 1894., što ga je dugi niz godina (od pokretanja do 1907. g.) uređivao Mercier (u suradnji s De Wulfom, kao tajnikom uredništva), držao se devize jezgrovito iskazane u svome podnaslovu: Nova et vetera - otvoriti dakle skolastičku misao modernoj filozofiji i znanosti i u tom je smislu preporoditi, učiniti neoskolastičkom. ${ }^{56}$ Ovdje nastojim, na primjeru Balićeva pristupa, pokazati da to otvaranje, da bi bilo potpuno, mora naći načina kako da prevlada bitnu razliku između tradicionalnoga (skolastičkog, srednjovjekovnog) i modernoga (novovjekovnog) pristupa. Upućujem pritom ukratko na louvainsko rješenje tog problema.

Kako smo već istaknuli, pod istinom Balić razumije u prvom redu dogme, istine katoličke vjere i morala, od Boga objavljene, tradicijom (još od apostolskih vremena) prenesene $s$ naraštaja na naraštaj, crkvenim autoritetom definirane i propisane. Te su istine neupitne, svete. Neke su među njima sadržaj same objave, izričit ili impliciran, u većoj ili manjoj mjeri dodatno interpretiran (primjerice, dogma Presvetog Trojstva, bezgrešnog začeća, nepogrešivosti pape itd.). Druge su opet iz tih u objavi sadržanih izvedene, i to strogim dokazom, nizom (ili mrežom) valjanih i neprijepornih zaključaka. ${ }^{57}$

Pod filozofijom pak, kako smo već istaknuli, Balić razumije razna sustavno razrađena mnijenja, sisteme, a ne istinu samu. ${ }^{58}$ U srednjem vijeku od filozofskih se sistema (augustinizma, tomizma, škotizma itd.) očekivalo da, uz ostalo, tumače objavljenu istinu, dogmu, da je brane od krivovjerjā, pogrešnih tumačenja, i da je sustavno razrađuju strogim dokazima dalje, u smjeru novih istina, dogmi. U novom vijeku filozofski sistemi (poput kartezijanizma, kriticizma, pozitivizma itd.) slobodni su od tih zadaća. ${ }^{59}$

Balićeva je koncepcija odnosa između dogme i filozofije tradicionalna. Istine katoličke vjere i morala norme su vrijednosti pojedinih filozofija (kako onih srednjovjekovnih, tako i modernih). Te su istine najprije negativni kriterij prihvatljivosti pojedinih filozofija: prema načelu veritativne solidarnosti, istina se istini ne protivi; dogme su pritom neupitne istine, iz čega slijedi da filozofija ne može biti ujedno

56 Usp. K. Grimm, U spomen kardinala Deziderija Merciera, 196.

57 Usp. K. Balić, Sv. Toma Akvinski..., 1, 110-111. O katoličkom pojmu i klasifikaciji dogmi usp. Daniel Coghlan, Dogma, u: The Catholic Encyclopedia, sv. V, 89-91.

58 Usp. K. Balić, Sv. Toma Akvinski..., 1, 110-111.

59 Usp. M. De Wulf, Scholasticism..., 190-192, 198-199; De Wulf, Western Philosophy..., 422-430. 
i istinita i dogmama oprečna. ${ }^{60} \mathrm{~K}$ tome, vrijednost pojedine filozofije mjerimo, između ostaloga, njezinim doprinosom razložnoj obrani pojedinih dogmi od raznih krivovjernih tumačenja i njezinim doprinosom daljnjoj razradi sustava dogmi, posebno u smjeru obogaćivanja tog sustava novim dogmama. ${ }^{61}$ Istine katoličke vjere i morala, dogme, nisu dakle tek negativni kriterij, prema kojem utvrđujemo prihvatljivost pojedine filozofije, nego su one ujedno i pozitivna norma, prema kojoj vrednujemo one filozofije koje negativni kriterij zadovolje, priklanjajući se najviše onima koje sustav dogmi najbolje interpretiraju i najuspješnije brane od krivovjernih tumačenja, te se u odnosu na nj pokazuju i najplodnijima, najviše pridonoseći njegovu obogaćivanju novim dogmama. Dogme doduše nisu jedina norma prema kojoj vrednujemo pojedine filozofije, ali one zacijelo u Balića jesu poprilično istaknuta i važna norma tog vrednovanja.

To je modernoj filozofiji strano. Ona je sekularna, slobodna od istina vjere i morala. O svojoj teološkoj vrijednosti ona ne vodi brigu. Posrijedi su dakle dva bitno različita pojma filozofije (srednjovjekovni i novovjekovni). U XIII. je st. aristotelizam osporavan između ostaloga i kao profana znanost te se uspio afirmirati tek dokazavši i svoju teološku vrijednost. U novome vijeku to mu više ne bi bilo potrebno. Istine katoličke vjere i morala nisu u novome vijeku norma prema kojoj vrednujemo pojedine filozofije.

Kao katolički pokret, neoskolastika ne može odstupiti od definiranih istina vjere i u tom se smislu ona u samoj svojoj koncepciji bitno razlikuje od moderne filozofije i znanosti. Koliko god im se dakle otvarala, ona neće nikad postati moderna u samu svome pristupu.

U sadržajnom pogledu, međutim, iz te koncepcijske razlike ne slijedi da se istine moderne filozofije i znanosti moraju kositi s istinama katoličke vjere. Različite koncepcije filozofije (ili znanosti) ne vode nužno do međusobno nepomirljivih spoznaja. Ni Aristotelova filozofija nije bila izvorno plod katolički koncipirana filozofiranja, pa se svejedno pokazala $\mathrm{u}$ mnogom pogledu i te kako spojivom $\mathrm{s}$ istinama katoličke vjere.

Unaprijed se dakle ne može znati, nego je potrebno istražiti, i to pomno, onako kako je Toma istražio Aristotela, tj. s punom i postojanom vjerom da u modernoj filozofiji i znanosti nema nepobitna dokaza protiv katoličkih dogmi. Ta vjera utkana je u temelje louvainskog otvaranja modernoj filozofiji i znanosti. Louvainska interpre-

60 Usp. K. Balić, Tomizam..., 5. Usp. također Lav XIII, nav. dj., 102-103; M. De Wulf, Scholasticism..., 192-193, 197-198; De Wulf, Western Philosophy..., 428-430.

61 Usp. K. Balić, Sv. Toma Akvinski..., 1, 92-93. Usp. također M. De Wulf, Scholasticism..., 194, 198, 271-272, 274. 
tacija načela veritativne solidarnosti sastoji se upravo u toj čvrstoj i postojanoj vjeri da moderna filozofija i znanost, slobodna od teologije, neće na koncu rezultirati spoznajom nespojivom s objavljenim istinama katoličke vjere i morala, nego, naprotiv, da će pridonijeti još boljem razumijevanju tih istina i daljnjoj njihovoj sustavnoj razradi, onako kako je to svojedobno učinila i Aristotelova filozofija, izvorno slobodna od teologije. Treba dakle dopustiti modernoj filozofiji i znanosti da se samostalno razvijaju, slobodno od teološke istine, i u tom im se smislu potpuno otvoriti, bez straha (kontrole), vjerujući da taj samostalan njihov razvoj ne samo da neće kakvim nepobitnim dokazom ugroziti objavljene istine katoličke vjere i morala nego cee im naprotiv barem nekim svojim dijelom još i pridonijeti. ${ }^{62}$

\section{ZAKLJUČAK}

Balićev pristup počiva na sljedećim trima temeljnim načelima.

Prvo, pravo razumijevanje neke filozofije (bilo skolastičke, bilo neskolastičke) moguće je samo u kontekstu njezina konkretnog povijesnog okruženja. Ljudski je um po svojoj naravi povijesno uvjetovan, a ne apsolutan. Svoju povijesnu uvjetovanost može on nadići samo nadnaravnom intervencijom, objavom. Objavljene su istine katoličke vjere i morala neupitne (svete) i apsolutne, o povijesnom kontekstu neovisne, nasuprot pojedinim filozofskim sistemima koji su plod naravnog, povijesno uvjetovanog čovjekova umovanja pa stoga i ne mogu opravdano pretendirati na apsolutnu vrijednost.

Drugo, objavljene istine katoličke vjere i morala nisu samo negativni kriterij, što ga svaka filozofija mora ispuniti, da bi nam uopće bila prihvatljiva (kao eventualno istinita), nego su one ujedno i pozitivna norma, prema kojoj vrednujemo pojedine filozofije što taj negativni kriterij zadovoljavaju. Priklanjamo se naime više onim filozofijama koje objavljenu istinu bolje objašnjavaju, sustavnije razrađuju i uspješnije brane od pogrešnih interpretacija. Pritom, objavljena istina nije jedina norma prema kojoj vrednujemo pojedine filozofije.

Treće, nema filozofije koja bi mogla iscrpsti svu nadnaravnu istinu. Svaka je filozofija povijesno uvjetovana, nasuprot nadnaravnoj istini, koja je apsolutna, nadpovijesna. Zato će svaka filozofija, koliko god da je uspješna u tumačenju, obrani i daljnjoj razradi sustava objavljenih istina, nužno ostaviti prostora i za drukčiji

62 Usp. J. L. Perrier, The Revival of Scholastic Philosophy in the Nineteenth Century, 182-183, 219, 220-221; M. De Wulf, Scholasticism..., 268-274, 276. Usp. također F. Barac, O modernoj katoličkoj apologetici, 110. 
pristup, unutar kojeg se uvijek može razviti i neka nova filozofija, podjednako dobra ili čak i bolja u tumačenju, obrani i daljnjoj sustavnoj razradi objavljenih istina. Nema stoga smisla taj potencijal uskoumno gušiti, to moguće bogatstvo u razlikama sprečavati, nego ga naprotiv treba prihvatiti i na nj poticati, gajiti dakle duh otvorenosti prema raznim pristupima, ne samo skolastičkima nego i modernima, bilo filozofskima, bilo znanstvenima.

Promotren u svome konkretnome povijesnom okruženju, Balićev sepristupzapravou svojimopćim crtamainepokazujeizvornonjegovim. ${ }^{63}$

Što se tiče povijesnoga momenta, louvainski je utjecaj najbolje objašnjenje. Došavši naime na louvainsko Katoličko sveučilište dvadesetih godina prošloga stoljeća, Balić se našao među nekim tada vodećim istraživačima povijesti skolastičke teologije i filozofije, tako da je bio u prilici i te kako dobro upoznati sve nijanse povijesnoga pristupa i sve prednosti što ih je taj pristup očitovao $u$ tom trenutku razvoja neoskolastičke misli. ${ }^{64}$

Što se tiče normativnog momenta, kako u smislu negativnog kriterija, tako i u smislu pozitivne norme, nalazimo ga u svih katoličkih filozofa, pa tako i u Balića i u louvainskih neotomista. Katolički filozofi kao takvi jednostavno ne mogu odstupiti od definiranih istina katoličke vjere i morala, niti bi mogli u potpunosti zanemariti vrijednost koju pojedina filozofija očituje u smjeru tumačenja, obrane i daljnje sustavne razrade tih istina.

Što se tiče načela otvorenosti prema raznim skolastičkim tradicijama i, posebno, prema modernoj filozofiji i znanosti, louvainski je Institut od sama svoga osnutka na tom načelu postojano inzistirao - dapače, na njemu je temeljio strategiju i program svoga razvitka ${ }^{65} \mathrm{U}$ Louvainu je dakle Balić, kao mlad filozof i teolog, još uvijek u fazi svoga sazrijevanja, po svoj prilici jednostavno uronio $\mathrm{u}$ tu otvorenost.

No s povijesnim se pristupom i načelom otvorenosti Balić mogao susresti i prije odlaska u Louvain, još u Hrvatskoj, čitajući primjerice Barca. Pritom, moramo imati na pameti činjenicu da je Barac i sam bio pod utjecajem posebno louvainskih neotomista: ne samo da se u Louvainu usavršavao nego je louvainske profesore (Merciera, de

63 Jasno, to se ne odnosi na samo Balićevo djelo, nastalo u okviru tog pristupa, koje je u mnogom pogledu i u mnogim pojedinostima i te kako originalno.

64 Među louvainskim profesorima koji su utjecali na Balićevo prihvaćanje povijesno-kritičkog pristupa Aračić izdvaja posebno De Meyera, Lebona i Bittremieuxa. Usp. D. Aračić, Karlo Balić, 17.

65 Usp. J. L. Perrier, The Revival of Scholastic Philosophy in the Nineteenth Century, 219-223. 
Wulfa i dr.) držao najznamenitijim predstavnicima neoskolastike, ${ }^{66}$ iz čega jasno slijedi da bi i taj eventualni Barčev utjecaj na Balićev pristup, kako u pogledu povijesnoga momenta, tako i u pogledu načela otvorenosti, bio zapravo (indirektno) louvainski.

Drugim riječima, izvore Balićevu pristupu moramo u prvom redu tražiti u Louvainu. Raniji utjecaji, prije odlaska u Louvain, bili su vjerojatno u filozofskom pogledu manje jasni, $\mathrm{k}$ tome barem dijelom možda i indirektno louvainski.

\section{BALIĆ'S APPROACH}

\section{Summary}

The main aim of this paper is to provide an integrated exposition of Balić's neo-scholastic approach. Various statements pertinent to the approach, mostly isolated from one another and scattered through Balić's works towards the very middle of the 20th century, were studied to serve as a basis for the exposition. As a result, three main features of Balić's approach were identified: firstly, the historical-critical method (explicitly preferred to the speculative approach); secondly, a sturdy adherence to Roman Catholic dogma as a norm for evaluating philosophical systems; and, thirdly, the insistent endorsement of the principle of intellectual freedom and openness to various scholastic systems as well as to modern philosophy and science (restricted only by dogma). In addition, this paper introduces some new arguments for the influence of Louvainneo-scholasticism on the formation of Balić's approach.

Keywords: Karlo Balić, historical-critical approach, integral scholasticism, Louainneo-scholasticism.

66 Usp. F. Barac, O modernoj katoličkoj apologetici, 95. Usp. također Ivica Zvonar, Prilog za životopis i monografiju radova mons. dr. Frana Barca, Senjski zbornik 2004., 79-94 (na str. 82); I. Zvonar, Mons. dr. Fran Barac..., 40-42; I. Zvonar, Dr. Fran Barac, 35-37. 